\title{
It Takes a Community
}

\section{Civic Life and Community Involvement Among Coös County Youth}

\author{
JUSTIN R. YOUNG
}

A mong the many notable features of Coös County, New Hampshire, is the region's high level of community engagement and a rich civic culture. Community and Environment in Rural America (CERA) surveys by the Carsey Institute have shown that nearly one-fourth of adults in the community report membership in a civic or fraternal organization, and an overwhelming majority agrees that residents can work together to resolve local problems. Yet we know relatively little about the role of youth in the community life of Coös County. Recent research suggests that, across the nation, levels of civic engagement among young people are greater than many might assume, though there is significant variation in youth involvement across different kinds of activities and from one region to the next. ${ }^{1}$

Places with a long history of civic life such as Coös County might exhibit higher levels of youth involvement than rural areas with long histories of inequality, underinvestment, and chronic poverty, where social ties are fewer and community cohesion lower, such as those in central Appalachia or the Mississippi Delta. ${ }^{2}$ Like adult residents, youth are one social resource that communities can draw on as they seek to resolve local problems and foster community well-being.

This issue brief explores the extent to which Coös County youth are involved in a variety of civic-related activities, with particular attention to the demographic and attitudinal factors associated with such participation. It also assesses the successes and struggles of local organizations in getting youth involved in community affairs.

\section{Coös Youth Study and In-Depth Interviews}

\section{Coös Youth Study}

In 2008, the Carsey Institute initiated the Coös Youth Study - an ongoing, decade-long project that surveys Coös County youth about their attitudes, behaviors, and perceptions of the county and their communities. Respondents

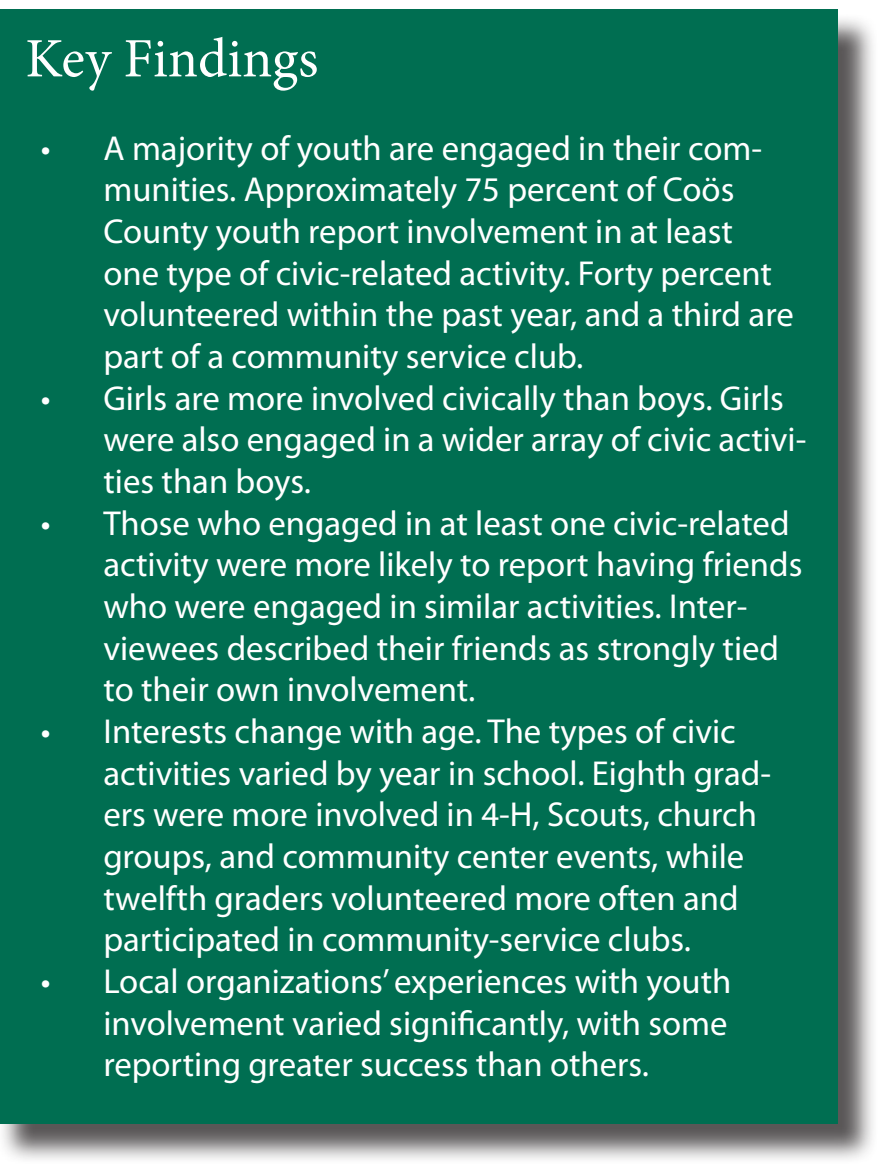

are also asked about their own aspirations (including those related to education, career, and family) and the extent to which they participate in a number of activities. Of interest here are the civic activities in which youth might be involved, including volunteer work, participation in community service clubs, 4-H/Scouts, attending community events (such as fairs and festivals), and community center events (such as those held at the YMCA or other centers). I also include participation in student government and church groups, given the civic skills gained by involvement in these 
activities, such as public speaking and attending/participating in meetings. ${ }^{3}$ Youth were surveyed again in 2009, when they were in the eighth and twelfth grade. I analyze data from this second wave, which includes 678 respondents. ${ }^{4}$

\section{In-Depth Interviews}

In addition to using the Coös Youth Study data, I conducted thirteen in-depth interviews in Coös County with young adults and various community resource leaders. These interviews constituted a project separate from the Coös Youth Study and were conducted for the purpose of this research brief. Four of these interviewees were high school graduates who were attending college at the time of the interview. Findings from these young adult interviews help to contextualize the survey results and shed light on the process by which youth become involved (and, in some cases, why they do not) in civic activities, along with the everyday experiences underlying their engagement. I also interviewed nine community resource leaders, service club directors, and service providers whose organizations provide opportunities for youth involvement. These interviews highlight the methods local organizations use in their search for volunteers and detail their experiences with Coös youth, their perceptions of youth involvement, and the outcomes of youth participation.

\section{Findings from the Coös Youth Study}

As Figure 1 illustrates, youth civic involvement varied widely across the range of activities examined. ${ }^{5}$ For instance, more than one-half of the study's respondents reported attending a community event in the past year, while fewer than 10 percent reported membership in 4-H or Scouts. This variation in activities notwithstanding, participation among respondents is quite high: nearly 75 percent of young adults reported engaging in at least one of these activities, and just under one-fifth said they participated in four or more (Figure 2). Further, one-third reported participating in a community service club, and 40 percent said they had done volunteer work outside the context of a service organization. While I do not have information on the specific number of activities (that is, the number of community events attended), these figures help to illustrate the breadth of youth involvement.

\section{Engagement Varies by Gender and Grade}

Past research from the Coös Youth Study has demonstrated that girls are more likely than boys to be involved in a wide range of activities. ${ }^{6}$ As Figures 1 and 2 illustrate, this gender gap persists to some extent in civic participation as well. Girls reported significantly higher rates of involvement in community service clubs, community events, and church groups (Figure 1).
Figure 1. CoÖS YOUTH PARTICIPATION RATES IN CIVICRELATED ACTIVITIES WITHIN THE PAST YEAR (2009)

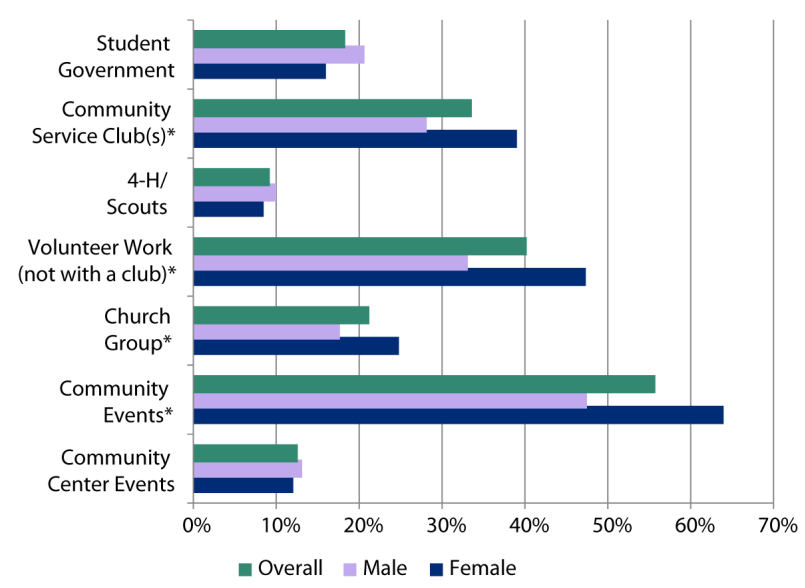

Notes: 1. Based on approximately 672 participants. 2. An asterisk indicates statistically significant differences ( $p<.05)$. 3. Source: Coös Youth Study (2009).

Figure 2. TOTAL TYPES OF CIVIC-RELATED ACTIVITIES INVOLVED IN DURING PAST YEAR (2009) FOR COÖS COUNTY YOUTH

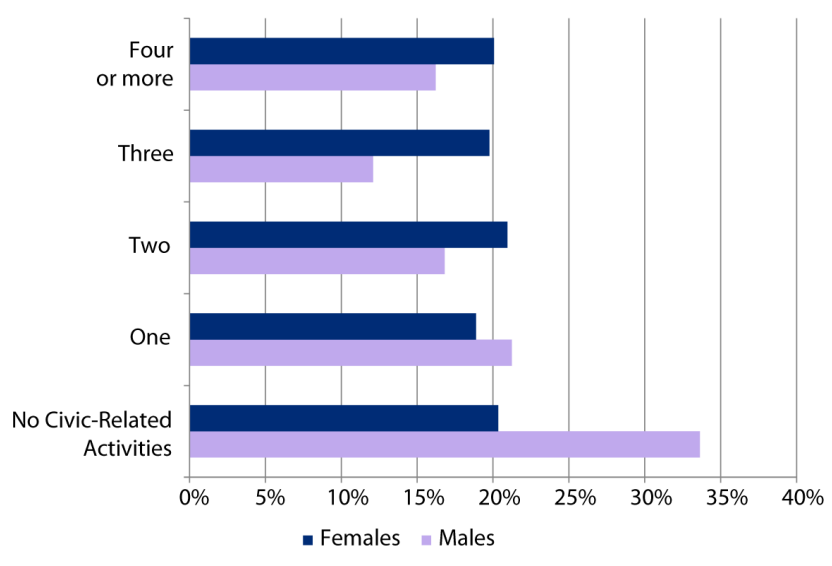

Notes: 1. Based on approximately 668 participants. 2. Source: Coös Youth Study (2009).

However, girls were no more likely than boys to note involvement in student government, 4-H, Scouts, or community center events. Girls did report participating in a wider variety of civicrelated activities (Figure 2), while boys more often reported no participation in any of these kinds of activities in the past year (34 percent versus 20 percent for girls).

Participation also differed by grade. Those in the eighth grade reported significantly more involvement in 4-H/Scouts, church groups, and community center events (see Figure 3 ), while twelfth graders reported higher rates of volunteer work and participation in community-service clubs. Thus, while the quantity of participation does not necessarily change over time, the types of activities do. It is likely that, as youth age, they settle on one or several types of activities and abandon others, as several young 
Figure 3. CoÖS YOUTH PARTICIPATION IN CIVIC-RELATED ACTIVITIES WITHIN THE PAST YEAR (2009), BY GRADE

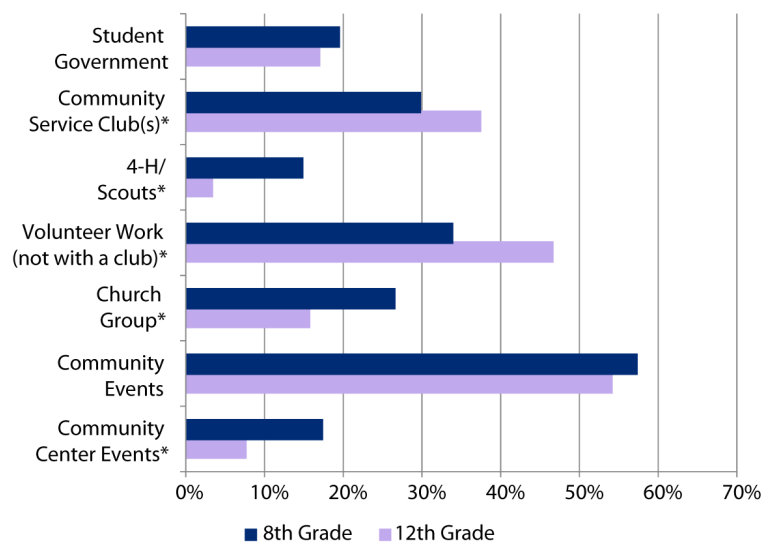

Notes: 1. Based on approximately 671 participants. 2. An asterisk indicates statistically significant differences $(p<.05)$. 3. Source: Coös Youth Study (2009).

adult interviewees suggested. The activities of organizations like 4-H, Scouts, church groups, and community centers might also be more attractive to younger teens, and such groups might reach out to younger cohorts of students for that reason. It is also possible, however, that differences between the two groups are not unique to age or their grade in school, but reflect more stable, long-term differences between these groups that do not change as they age. Examining data from only one survey year limits our ability to determine whether this is the case.

Participation in one activity over another is likely tied to other demands as well. For instance, all interviewees cited doing some form of volunteer work near the end of high school in part with the college application in mind. As one noted, "Having something like that [volunteer work] helped rather than having a blank résumé." While interviewees described getting started in civic and extracurricular activities at a young age (typically elementary school), the activities in which they participated changed as they grew older. With respect to the study's data, though, no grade-related differences exist in two specific forms of participation (community events and student government), suggesting that involvement in these particular activities remains stable as Coös youth navigate their teen years.

\section{Family and Friends May Matter for Youth Engagement}

As teens progress through high school, their social networks are often interrelated with their civic involvement. Not surprisingly, interviewees described their friends' plans to participate in various activities as closely linked to their own. They also described attempts to surround themselves with peers who were more involved, suggesting that engagement in community activities itself may foster peer relationships. The study's results (Figure 4) speak to both these inclinations. The respondents who agreed they have a
FIGURE 4. RESPONSES TO "I HAVE A GOOD GROUP OF FRIENDS IN MY COMMUNITY” FOR THOSE REPORTING PARTICIPATION IN VARIOUS CIVIC ACTIVITIES

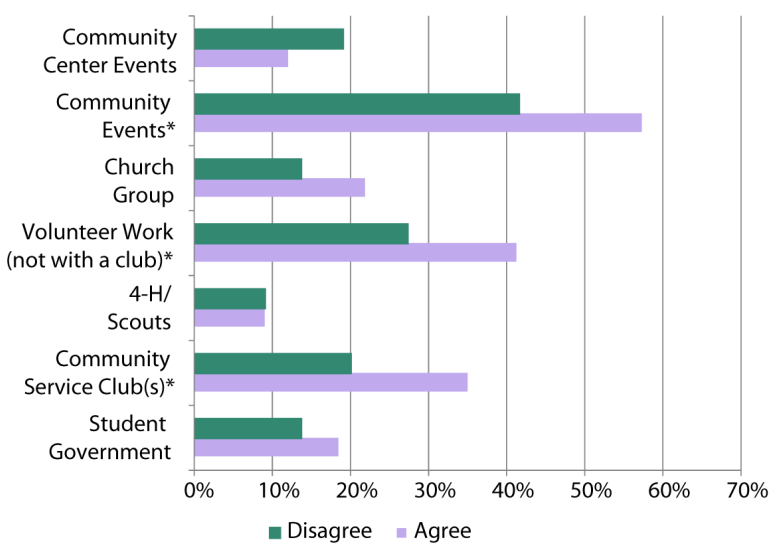

Notes: 1. Based on approximately 668 participants. 2. An asterisk indicates statistically significant differences ( $p<.05)$. 3. Source: Coös Youth Study (2009).

good group of friends in their community were much more likely to report attending a community event, volunteering, and working with a community service club. Survey respondents were also asked about some of their and their friends' plans for the near future, including whether they planned to volunteer. Not surprisingly, nearly 60 percent of those who said they were at least somewhat likely to volunteer said that most or all of their friends were likely to do so as well. This compares with fewer than one-fourth of those with no friends who planned to volunteer.

\section{Community Perceptions and Concerns Are Linked to Youth Civic Life}

"I just really like helping people, and became really involved." This seemingly simple link between a respondent's values (helping people) and involvement highlights the association between youths' perceptions of their communities and their role in local civic life-a relationship illustrated in Figure 5. More specifically, engagement in any one of these civic activities is highly correlated with positive perception of community cohesion, including neighborliness and feeling that one's community is closely knit. Youth engaged in none of these civic-related activities are less likely to report positive perceptions of their communities than those who participate in even one of these types of activities. This trend is similar across all measures of community attachment, although whether such attitudes encourage youth to participate or they develop such attitudes once they become engaged is unclear.

In rural areas, it is often the youth with higher levels of community involvement and/or the greatest academic success who plan to leave their communities in search of 


\section{FiguRE 5. COÖS YOUTH PERCEPTIONS OF THEIR} COMMUNITIES BY CIVIC ENGAGEMENT STATUS

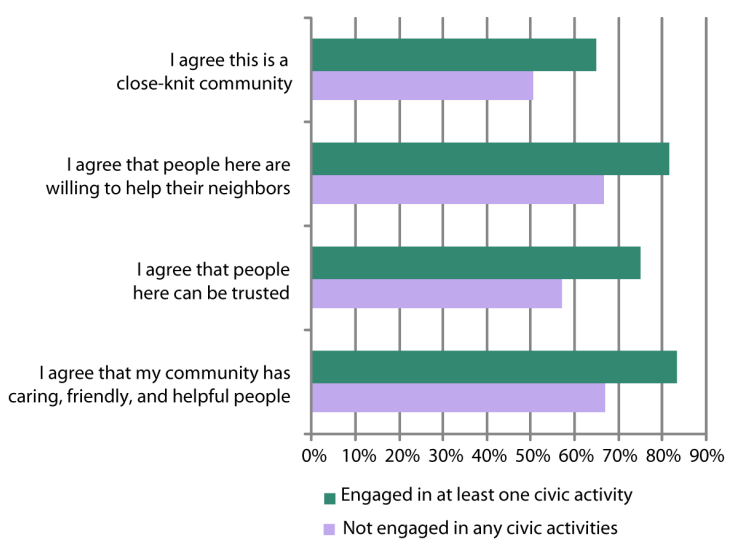

Notes: 1. Based on approximately 657 participants. 2. Source: Coös Youth Study (2009).

opportunity elsewhere. ${ }^{7}$ Indeed, nearly two-thirds of those engaged in one or more civic activities said it was at least somewhat likely that they would leave the area after high school, compared with fewer than one-half of those not engaged in any of these activities. Past research from the Coös Youth Study indicates, however, that Coös youth who identify strongly with their communities also place a greater emphasis on living in their hometowns, suggesting that those who leave for college may be more likely to return than those who leave for other reasons. ${ }^{8}$ Among interviewees, feelings about and reasons for returning were mixed. Only one said she would not mind moving back to Coös County, though she had no specific plans to do so. The remaining interviewees said they would not move back to the area. Two cited an immediate lack of job opportunities, while another stated she disliked the small-town atmosphere. Interviews with organization leaders suggest that those attempting to engage rural youth in Coös County were often aware of their plans to leave the area, although this did not seem to have much bearing on whether or not they offered youth opportunities to participate in their organizations.

\section{The Struggles and Successes of Local Organizations}

Despite the high levels of involvement among youth, organization leaders in Coös County described conflicting experiences in fostering youth and young adult involvement. These leaders represented a variety of associations that regularly offer opportunities for youth engagement, including social service agencies, community service clubs, volunteer groups, and community centers. Success varied not only by the size of the organization - with larger, more well known organizations able to garner more participants-but also by the types of activities and the extent of connections with other local institutions (most notably Key Club-a national civic organization for youth with various local branches-and schools, although success with the latter was mixed). One organization leader noted that their organization catered specifically to those under 18 , and the remainder offered positions for both youth and adults alike.

\section{Organizations Recruit Youth from a Variety of Sources}

The types of civic-related activities for which organizations most often recruited youth included community dinners, picnics, art and theater projects, recreational activities, and participation in community fairs and other events. Some also offered youth unpaid internships, particularly social serviceoriented organizations. Organization leaders reported drawing on local Rotary, Key Club, and National Honors Society chapters, Boy Scouts, Girl Scouts, and sometimes school districts and nearby colleges to recruit youth. One organization leader noted that youth often heard of her center's recreation events via their participation in high school sports, a factor that helps to explain the link between community engagement and involvement in other non-civic activities.

Young adult interviewees noted that their parents encouraged their involvement, and some organization leaders stated they have been successful in instilling civic-mindedness in their own children. Three of these leaders in particular said that their children were involved in their own organization or another organization linked to civic engagement. Other organization leaders stated that youth often heard about opportunities through their parents, who were already involved in the organization or one with close ties to it. In addition, one noted that she was successful in recruiting some of her daughter's friends as volunteers, while another stated that their young adult members often brought in friends who were interested in volunteering. Patterns such as these reflect the importance of family ties and parental attitudes toward community life. ${ }^{9}$

Three noted that they often relied on Key Club to garner younger volunteers and to help spread the word about events. Those who networked with local Key Clubs described a significant degree of success. "Key Club is such an excellent way to teach kids how you volunteer," one leader noted. Others also described the organization as one that helps to cultivate civic engagement among the county's young adults. Success with local school districts was mixed, however. One organization leader noted that at least one school in the county requires some form of community service for graduation, a trend that she noted has had a positive impact on her organization's ability to recruit young volunteers. "It introduces the youth at a young age to giving back to the community. As they get older...it would cultivate that spirit." While one person noted that youth seeking to fulfill such obligations often left as soon their requirements were satisfied, experiences with these youth were mostly positive. 
Others described their success with local school districts as more sporadic, particularly those who lacked regular contacts with the schools, whose organizations were smaller or required volunteers with specific skills (such as a driver's license, proficiency with computers, or knowledge gained via long-term training).

\section{Economic Struggle and Demographic Change Tied to Youth Civic Involvement}

Several leaders mentioned that the county needs a more formal means by which to recruit volunteers of all ages, which might also ease the struggle to recruit youth. As one noted, "We need...a database that everyone could go into and look at. We do have RSVP [Retired Senior Volunteer Program] and they service people 55 plus, but there are a lot of people under 55 capable of volunteering and probably would if they knew we existed." In many ways, the RSVP reflects the county's aging population, providing convenient access to a substantial pool of volunteers. Although this interviewee noted there has been talk of developing such a database to connect young adults to organizations, the funding and time needed to develop it are lacking, she said. Another added that the county might consider drawing on volunteers familiar with RSVP to develop a broader network that included youth.

Organization leaders also cited outmigration of the county's young adult population as an issue that exacerbates their problems getting youth involved, particularly among those just out of high school. ${ }^{10}$ Although two young adults interviewed noted they moved to Coös County in their teens, they are the exceptions in the youth population in Coös, and current demographic trends have taken a toll on youth engagement according to organization leaders. "Generally the brightest, most go-getter kids are leaving the area," one said. Again, while the study's data suggest that civically engaged youth were more likely than those not engaged to emphasize the importance of living in their hometowns, whether they will return remains to be seen.

Yet another impediment to finding volunteers was the lack of outreach avenues. One leader, for instance, lamented the loss of a local radio station, which her organization was once able to rely on to spread the word about volunteer work, community events, and other opportunities for both youth and community members more broadly. Another described her organization's publicity constraints similarly: "Sometimes I just don't think they (youth) know the opportunities are there." Young adults also cited the importance of publicity. Those involved in Key Club described it as being well promoted, citing the use of fliers, announcements, and word-ofmouth from other participating students and teachers. The young adults interviewed also noted that the organization sent members to speak at their high school orientations.

Like young adults, organization leaders perceived a need for more youth leadership and involvement. As one leader noted, "There should be some minimum requirement where kids get involved and give back to their community. It's something that we need to cultivate in our young people to give them some ownership in the community." All organization leaders mentioned the importance of fostering a sense of ownership among young people to ensure that they have a stake in what happens in their communities and to instill the importance of participation as adults.

\section{Conclusion: Fostering Future Involvement and Attachment}

In places like Coös County, residents routinely invest in their communities as they work together to solve local problems and contribute to the well-being of their communities. Engaging youth in local civic activities is thus an important part of integrating them into the community and providing them with a set of civic skills they can draw on in adulthood. Both the interviews with young adults and organization leaders, along with the survey data from the Coös Youth Study, illustrate that youth do in fact play a role in the civic culture of Coös County. Involvement among youth is generally high, particularly with respect to attending community events, volunteering, and participating in community service clubs. Moreover, roughly one in five youth reported engaging in at least four types of civic activities, although there is variation, at least by gender and year in school.

In fostering more involvement, local organizations may be able to use older, established residents to spur more youth involvement by, for example, drawing on those enrolled in the county's RSVP program to find volunteers whose time could be used specifically to expand their outreach and young-adult volunteer base, depending on the program's available resources. Organizations might also intensify their networking with guidance counselors and other school leaders, as well as local groups like Key Club, National Honors Society, and Builders (an offshoot of Key Club for younger teens) to form a program similar to RSVP. Gender differences in participation pose another unique challenge to organization leaders, with young boys less engaged than girls. Although why this variation persists is unclear, it nevertheless highlights an untapped source of community participants. A broader emphasis on youth participation in general could potentially narrow this gap.

No matter the approach to fostering greater civic engagement among Coös County youth, organizations, resource leaders, social service agencies, and educators should keep in mind that engaging youth in civic life is clearly a community-wide undertaking. Although parents, for instance, can cultivate dedication to community in their children, as some young adults and organization leaders indicated, opportunities must be made available and visible. To that end, school 
administrators should consider incorporating more opportunities for local organizations to publicize their missions and calls for volunteers. A combination of such approaches might be best in fostering greater civic engagement among youth and in doing so reproduce the bonds of community historically characteristic of Coös County.

\section{E N D N O T E S}

1. Cliff Zukin et al., A New Engagement? Political Participation, Civic Life, and the Changing American Citizen (New York: Oxford University Press, 2006); Mark Hugo Lopez et al., "The 2006 Civic and Political Health of the Nation: A Detailed Look at How Youth Participate in Politics and Communities" (Medford, MA: Center for Information and Research on Civic Learning and Engagement, Tufts University).

2. Cynthia M. Duncan, Worlds Apart: Why Poverty Persists in Rural America (New Haven, CT: Yale University Press, 1999); Lawrence Hamilton et al., Place Matters: Challenges and Opportunities in Four Rural Americas, A Carsey Institute Report on Rural America (Durham, NH: Carsey Institute, University of New Hampshire, 2008).

3. Sidney Verba, Kay Lehman Schlozman, and Henry E. Brady, Voice and Equality: Civic Voluntarism in American Politics (Cambridge, MA: Harvard University Press, 1995).

4. While past Carsey Institute research has also addressed issues of after-school activities and community attachment, youth community contributions and the civic roles they fill in Coös County have not been examined before now; see Erin Hiley Sharp, "Out of School Time Matters: Activity Involvement and Positive Development among Coös County Youth," Issue Brief No. 17 (Durham, NH: Carsey Institute, University of New Hampshire, 2010); Erin Hiley Sharp, “Too Much Free Time: Coös County Youth Who Are Least Involved in Out-ofSchool Activities Are Most Likely to Use Drugs and Alcohol," Issue Brief No. 18 (Durham, NH: Carsey Institute, University of New Hampshire, 2010); Genevieve R. Cox and Corinna Tucker, "No Place Like Home: Place and Community Identity among North Country Youth," Issue Brief No. 24 (Durham, NH: Carsey Institute, University of New Hampshire, 2011).

5. Only differences that are statistically significant at the $\mathrm{p}<.05$ level are discussed in this brief.

\section{Sharp, "Out of School Time Matters."}

7. Patrick J. Carr and Maria J. Kefalas, Hollowing Out the Middle: The Rural Brain Drain and What It Means for America (Boston: Beacon Press, 2009).

\section{Cox and Tucker, "No Place Like Home."}

9. See also Corinna Tucker, "Stay or Leave Coös County? Parents' Messages Matter," Issue Brief No. 14 (Durham, NH: Carsey Institute, University of New Hampshire, 2009).
10. For a brief overview of demographic trends in Coös County and elsewhere in New Hampshire, see Kenneth M. Johnson, The Changing Faces of New Hampshire: Recent Demographic Trends in the Granite State, Reports on New England, Vol. 1, No. 1 (Durham, NH: Carsey Institute, University of New Hampshire, 2007).

\section{ABOUT THE AUTHOR}

Justin R. Young is a doctoral student in sociology at the University of New Hampshire and a research assistant at the Carsey Institute (jrobertyoung@gmail.com).

\section{A C K N O W L E D G M E N T S}

The author wishes to thank Peter C. Nordblom and Kristin Van Curan Nordblom and Neil and Louise Tillotson Fund of the New Hampshire Charitable Foundation, whose support made this research project possible. I am grateful to the community leaders and young adults of Coös County for sharing their stories. Thank you also to Curt Grimm, Michele Dillon, and Bruce Mallory who offered guidance and constructive feedback throughout the course of this research. Also, thanks to the members of the Coos Youth Study research team, including Eleanor Jaffee, Cesar Rebellon, Erin Hiley Sharp, Corinna Jenkins Tucker, and Karen Van Gundy.

\section{A UNIVERSITY Fi. of NEW HAMPSHIRE}

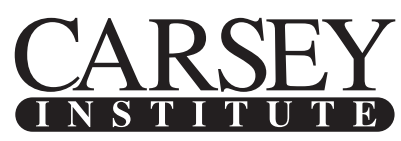

Building knowledge for families and communities

The Carsey Institute conducts policy research on vulnerable children, youth, and families and on sustainable community development. We give policy makers and practitioners timely, independent resources to effect change in their communities.

This work was supported by Peter C. Nordblom and Kristin Van Curan Nordblom and the Neil and Louise Tillotson Fund of the New Hampshire Charitable Foundation.

Huddleston Hall

73 Main Street

Durham, NH 03824

$(603) 862-2821$

www.carseyinstitute.unh.edu 